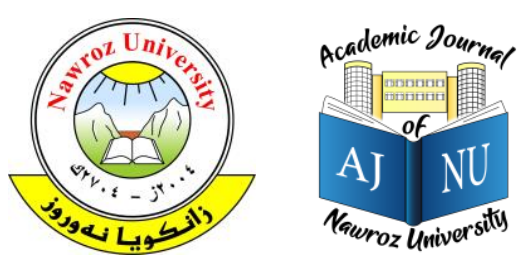

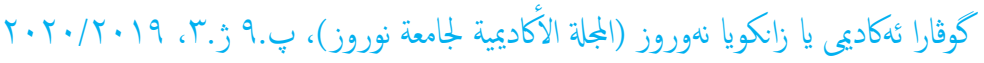

حقوق الطبع والنشر ؟2017. هذه مقالة الوصول اليها مفتوح موزعة تحت رخصة

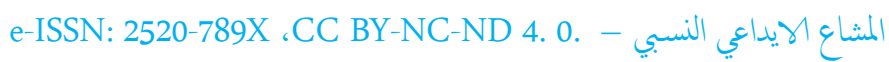

https://doi.org/10.25007/ajnu.v9n3a840

\title{
دور نظم المعلومات التسويقية في تحقيق الميزة التنافسية: \\ دراسة لآراء عينة من العاملين في عدد من فنادق مدينة دهوك
}

م سليمان احمد حسين، قسم ادارة اعمال (زائر في جامعة نوروز)، جامعة دهوك، كردستان العراق

مهدف البحث التحديد دورنظم المعلومات التسويقية في تحقيق الميزة التنافسية في فنادق مدينة دهوك. وتضمن مجمع الدراسة عدد من الفنادق العاملة في مدينة دهوك ، واخذت عينة عشوائية من هذه الفنادق بلغت (40) فندقا ، واستخدم الباحث استارة استبيان كأداة رئيسية لمحع البيانات والمعلومات اللازمة وتم توزيعها على العاملين في تلك الفنادق، واسترجع منها (30) استارة صحيحة فقط وبنسبة (75\%) ، وتوصل البحث المى عدم وجود علاقات معنوية بين نظم المعلومات التسويقية والميزة التنافسية بشكل عام ، باستثناء نظام الاستخبارات التسويقية بشكل منفرد ، واوصى البحث بضرورة

استخدام التكنولوجيا ونظم المعلومات التسويقية المتطورة في الفنادق المعينة بالدراسة ليعزز دورها في تحتيق الميزة التنافسية في عملها .

الكلمات المفتاحية: عناصر التدقيق التسويقي، تدقيق الوظيفة النسويقة، تدقيق الانتاجية التسويقي ،تدقيق الاظظمة التسويقية،الاداء التسويتي.

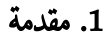

يعد تطور تكنولوجيا المعلومات من اهم الابتكارات التي احدثت تغيرا جذريا في

مختلف نواحي الحياة، اي ان استخدام نظم المعلومات التسويقية في السنوات الاخيرة 2. المحور الاول: منهجية البحث

اصبحت من اهم الادوات التي يعتمد عليها في مجال التسويق ، وتمثل التكنولوجيا محور 1.2 مشكلة البحث

عملية التقدم وهذا ما يتيح للفنادق ايضا قدرتا على التنافس وتحقيق قدرات ميزة لها . من خلال الاستطلاع الميداني الذي قام به الباحث لعدد من الفنادق في مدينة وتدرك الفنادق ان بقاؤها وتقدما يتمثد على القدرات التكنولوجية التي يمتلكها، وتتسم دهوك، و اجراء عدد من المقابلات مع عدد من مديري تلك الفنادق ، تبين للباحث نظم المعلومات التسويقية بالحركة والتغير المستمر ، ولهذا فهي تعد بمثابة ديموة الحياة بان الفنادق المعينة بالدراسة لديها ضعف في الاهتمام بوجود نظام المعلومات التسويقية للمنظات ، كونها تضمن النمو و الوستمرارية ، واليوم اصبح من الضروري لانجاح لديها ، وهذا ما ينعكس بدوره على تحقيق التميز لها في سوق الفنادق الخاصة لمدينة عملية المنافسة التسويقية وجود نظم المعلومات التسويقية نابحة تقوم بالعديد من دهوك ، وينعكس ذلك على قدرة تلك الفنادق في تحقيق ميزتها التنافسية والخاص رك رك الانشطة التسويقية بهدف تحقيق الميزة التنافسية للفنادق في السوق الذي تعمل فيه. بالخدمات الفندقية التي تقدما و ينسحب ذلك على خدمة الزبون والحصة الزبونية وقد جاء البحث الحالي كساهمة متواضعة للهوض بواقع عمل الفنادق في مدينة دهوك، والسوقية لتلك الفنادق · ويكن صياغة مشكلة البحث من خلال السؤال البحثي وما تعانيه من مشكلات في ظل الطروف الحرجة التي يمر بها الاقليم ، وتضمن الرئيسي ( هل ان وجود نظم المعلومات التسويقية في الفنادق عينة الدراسة ، تلعب البحث اربعة محاور، احتوى المحور الهول على نهجية البحث والمحور الثاني تطرق الى دورها في تحقيق الميزة التنافسية ) و يتفرع عن السؤال هذا عدد من الاسئة البحثية

الجانب النظري والدراسات السابقة عن نظم المعلومات التسويقية والميزة التنافسية ، ومنها :

هل يوجد نظام للمعلومات التسويقية في الفنادق عينة البحث .

• اما المحور الثالث فتضمن الجانب التطبيقي للبحث واخيرا المحور الرابع تضمن النتائُ والمتتزحات . 


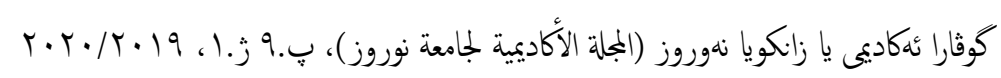

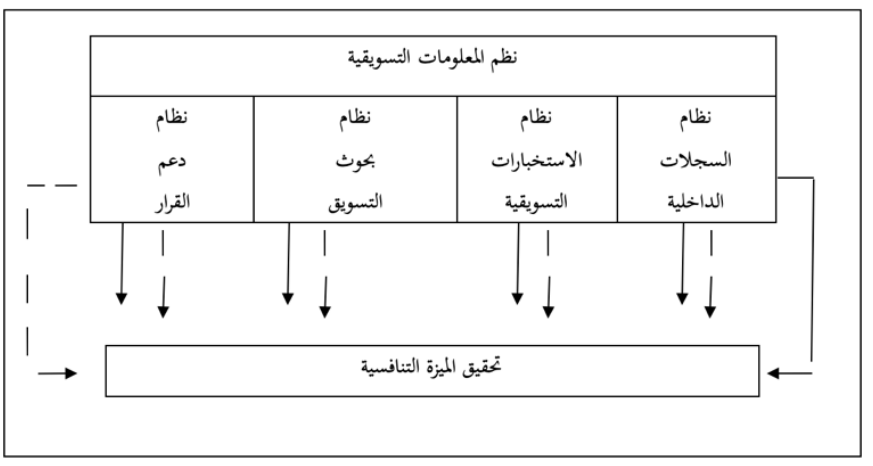

الشكل 1. الخمطط الافتراضي للبحث

الملاحظة المخد

ـ

البحث على فرضيتين رئيسيتين:

توجد علاقة ارتباط معنوي بين مكونات النظام المعلومات التسويقية والميزة التنافسية عند مستوى معنوية (0.05) . وحسب الفرضية يككن اشتقاق

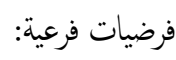

توجد علاقة ارتباط بين قاعدة البيانات (السجلات الداخلية ) و الميزة

$$
\text { التنافنية عند مستوى معنوية (0.05). }
$$

توجد علاقة ارتباط بين نظام الاستخبارات التسويقية و الميزة التنافسية

$$
\text { عند مستوى معنوية (0.05).. }
$$

توجد علاقة ارتباط بين نظم بحوث التسويق و الميزة التنافسية عند

$$
\text { مستوى معنوية (0.05). }
$$

توجد علاقة ارتباط بين نظم دع القرارات و الميزة التنافسية عند مستوى

$$
\text { معنوية (0.05). }
$$

ب. توجد تاثير لمكونات النظام المعلومات التسويقية في الميزة التنافسية وعند

$$
\text { مستوى معنوية(0.05)، وحسب الفرضية توجد فرضيات فرعية اخرى : }
$$

توجد تاثير لمكون النظام المعلومات التسويقية في زيادة الحصة التسويقية

$$
\text { للفندق عند مستوى معنوية(0.05) . }
$$

توجد تاثير لمكون النظام المعلومات التسويقية في سمعة الفندق عند

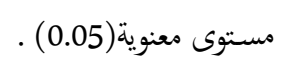

هل يدرك العاملون في الفنادق بان وجود نظام المعلومات التسويقية فهيا يوثر

$$
\text { على تحقيق الميزة التنافسية لها . }
$$

هل يوجد علاقة ارتباط وتأثير لنظام المعلومات التسويقية مع تحقيق الميزة

$$
\text { التنافسية . }
$$

2.2

$$
\text { تظهر اهمية البحث في جانبين رئسين وها: }
$$

المستوى الكاديمي : اذ يمثل البحث الحلالي جانبا حما في الاطار النظري، حيث

يعد اضافة معرفية لعلم التسويق ولمككتبة والباحثين،حيث يككن الاستفادة منه

يقوم

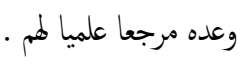

المستوى الميداني : حيث يمكن للفنادق في مدينة دهوك الاستفادة من نتائجه

ومقترحاته حاليا او مستقبلا في بناء نظام المعلومات التسويقية والذي يعزز من

قدراتها التنافسية في المستتبل .

$$
\text { نحاول عن طريق هذا البحث ان نصل الى الاهداف الآتية : }
$$

تشخيص واقع عمل الفنادق المدروسة ومدى امتلاكها لوجود نظام معلومات

$$
\text { تسويقية. }
$$

تشخيص مدى وجود علاقة ارتباط بين مكونات نظم المعلومات التسويقية

$$
\text { والميزة التنافسية . }
$$

تشخيص مدى تأثير مكونات نظم المعلومات التسويقية في تحقيق الميزة

$$
\text { التنافسية في الفنادق عينة البحث . }
$$
يقدم البحث عدد من المقترحات المفيدة والمعقولة المى الفنادق المشمولة بهذا البحث في مدينة دهوك. 


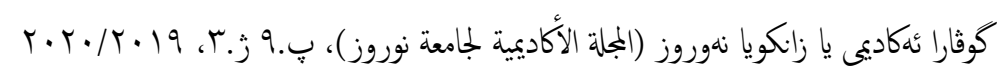

معاملات الثبات بطريقة (الفا -كرونباخ ).

\begin{tabular}{|c|c|c|}
\hline معامل الثبات & عدد الفقرات & الجمال \\
\hline 0.80 & 11 & نظام المعلومات التسويقية \\
\hline 0.78 & 19 & الميزة التنافسية \\
\hline 0.84 & 30 & الاجليلي \\
\hline
\end{tabular}

تبين من الجدول (1) بان معاملات اثبات لمتغيرات البحث (النظام المعلومات و الميزة التنافسية ) بلغت (0.80 و 0.78 ) على التوالي و معامل الثبات الاجلالي بلغ (0.84) و هي قيمة مقبولة للتطبيق في الدراسات العلمية والانسانية .

9.2 وصف الخصائص الديغرافية اعتمد الباحث على الخصائص الديمغرافية للمبحوثين من حيث العمر والجنس و المستوى العلمي للعاملين في الفنادق .ويكن توضيح الخصائص الديمغرافية للمبحوثين

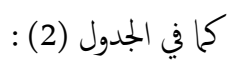

جدول 2

وصف الخصائص الديمرافية للمبحوثين

\begin{tabular}{|c|c|c|c|}
\hline النسبة المثوية & العدد & الشخصية & المميزات \\
\hline 0.80 & 24 & ذك & الجنس \\
\hline \multirow[t]{2}{*}{0.20} & 6 & انتى & \\
\hline & 30 & المجموع & \\
\hline 6.6 & 2 & $24-20$ & العمر \\
\hline 16.6 & 5 & $29-25$ & \\
\hline 56.6 & 17 & $34-30$ & \\
\hline \multirow[t]{2}{*}{20} & 6 & 39-35 & \\
\hline & 30 & المجموع & \\
\hline 3.3 & 1 & ابتدائي & \\
\hline 26.6 & 8 & متوسطة & المستوى العلمي \\
\hline 40 & 12 & اعدادية & \\
\hline 23.3 & 7 & دبلوم & \\
\hline \multirow[t]{2}{*}{6.6} & 2 & بكالوريوس & \\
\hline & 30 & & \\
\hline
\end{tabular}

تبين من الجدول (2) :
توجد تاثير لمكون النظام المعلومات التسويقية في رضا الزبون عند

مستوى معنوية(0.05) .

توجد ثاثير لمكون النظام المعلومات التسويقية في التميز اي الابداع

$$
\text { والابتكارات عند مستوى معنوية(0.05) . }
$$

توجد تاثير لمكون النظام المعلومات التسويقية في استخدام التكنولوجيا في

$$
\text { الفندق عند مستوى معنوية(0.05) . }
$$

6.2 مجمع البحث وعينه

تكون مجتع البحث من بمحوعة من الفنادق في مدينة دهوك ، واخذت عينة عشوائية من هذه الفنادق بعدد (40) فندقا وتم توزيع استلارات الاستيان على العاملين في هذه الفنادق بمعل(40)استارة واستزجع (30) استتمارة صالحة للبحث اي بنسبة

\section{2 جمع المعلومات والبيانات}

اعتمد في الجانب النظري للبحث على البحوث المتوفرة وعدد من الكتب والدراسات والانتيت والمواضيع والمقلات المنشورة وكذلك رسائل الماجستير و اطاريخ

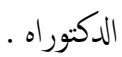
اما في الجانب الميداني تم الاعتماد على استمارة الاستبيان كصدر اساسي للبيانات والمعلومات ، وخصصت هذه الاستارة على شكل تكون سهلة وتناسب مع واقع البحث وكذلك تم الاعتماد على مقياس (ليكرت) التي ينكون من (5) درجات و

\begin{tabular}{|c|c|c|c|c|}
\hline لا اوافق بشدة & لا اوافق & محايد & موافق & موافق بشدة \\
\hline 1 & 2 & 3 & 4 & 5 \\
\hline
\end{tabular}
كالآتي :

8.2 أ. معامل (كرونباخ - الفا ) لقياس الثبات وصدق المعلومات . ب. الارتباط والانحدار لقياس علاقات الارتباط والانحدار بين متغيرات البحث . ثبات اداة الدراسة: لتثبيت و تحقيق ثبات الاداة تم تطبيق معادلة (الفا - كرونباخ ) على جميع الفقرات كما مبين في الجدول(1) : جدول 1 


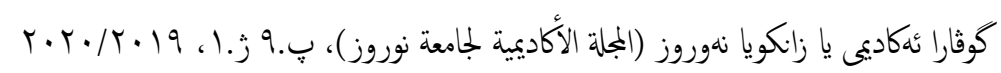

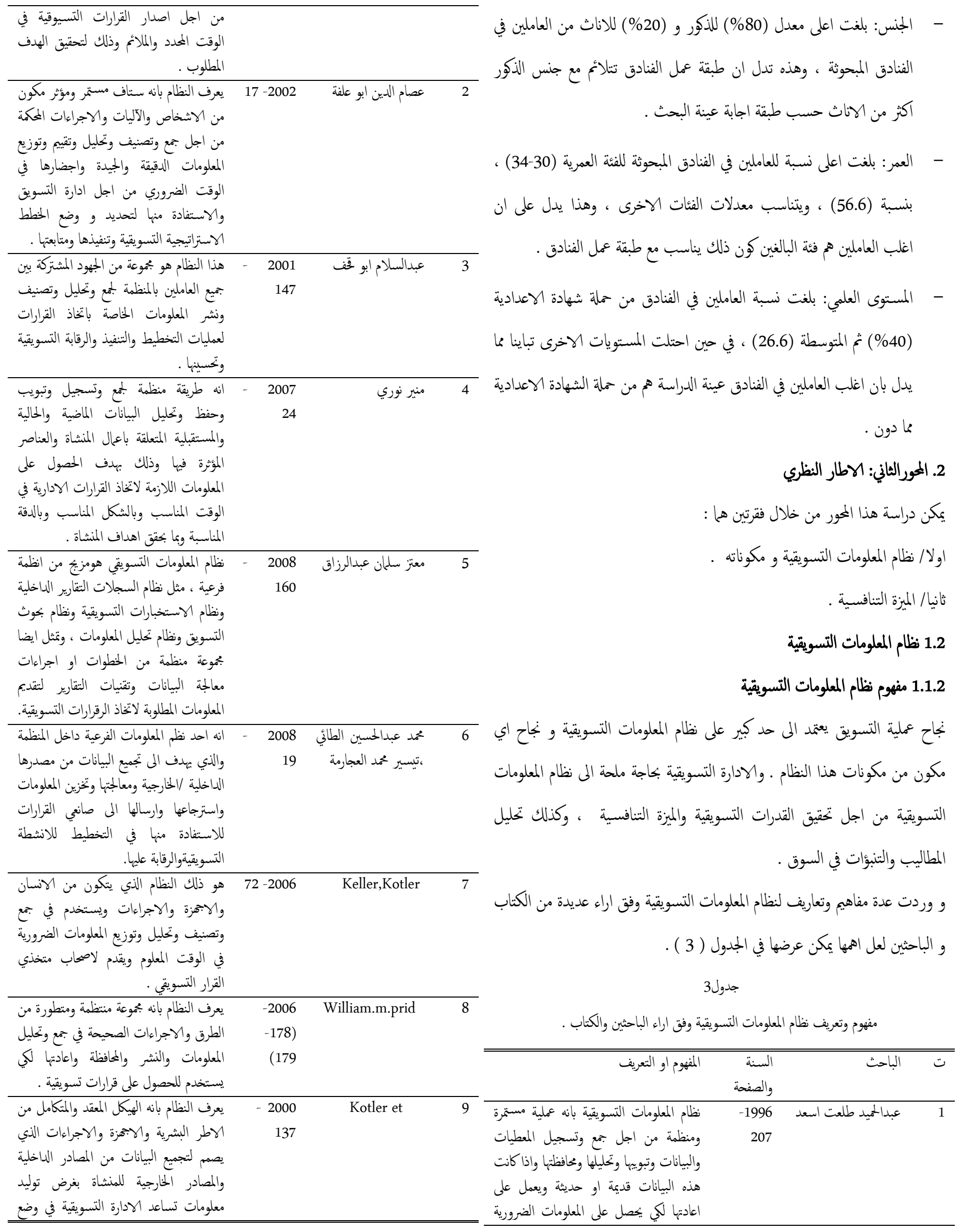




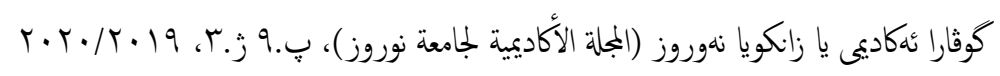

ب. ايجاد منظومة بياتا تكون ضامنة لربط العلاقة مابين البيانات القديمة والجديدة،

وفي النهاية اصدار بعض البيانات والمعلومات الضرورية لاصحاب القرارات .

ج. استخدام الناذج الجيدة للاحصاء واعطاء المعلومات الى كافة مستويات

$$
\text { الادارية لتكون صالحة وجيدة لاصحاب القرارات . }
$$

\subsection{2 مكونات النظام المعلومات التسويقية}

يتكون النظام المعلومات التسويقية من المكونات النالية (الزعبي ، 2005 :

$$
\text { و(الصحن والسيد ، } 2003 \text { : } 133 \text { ) : }
$$

أ. السجلات الداخلية: اي قاعدة البيانات ويعرف بانه نظام خاص بالمعلومات

$$
\text { المتعلقة بالطلب و دفع الثمن . مان. }
$$

ب. الاستخبارات التسويقية: اي نظام الذكاء وهو بمحوعة من الاجراءات في

المؤسسة التي تهدف المى توزيع المعلومات التسويقية ـ و يمكن ان نقول بانه بموعة من الاشخاص والاجراءات والاجهزة التي تستخدم باساليب قانونية

واخلاقية .

نظام المساندة للقرارات التسويقية: يستخدم الدوائر والمؤسسات والثركات هذا النظام والاساليب في عملية جمع وتحليل البيانات والمعلومات ، ويتكون هذا النظام من المؤشرات الاحصائية وتماذج القرارات والبرامج لمساعدة مديري التسويق في تحليل البيانات والمعلومات و ترشيد عملية اتخاذ القرار . د. بحوث التسويق: وهو نشاطات وعمليات لجمع البيانات والمعلومات المطلوبة من المصادر الاساسية وتحليلها واستخداما وفي النهاية تقديم التقرير الوافي لمديري

$$
\text { التسويق .( عبيدات - } 2003 \text { : } 13 \text { ). }
$$

2.2

أ. مغهوم الميزة التنافسية : اصبحت الميزة التنافسية ثورة في ادارة الاعمال على المستويين الكاديي والعملي ، فينظر الادارة المستوى الاكاديي بانه عملية ديناميكية مستمرة وتهدف المى معالجة المشاكل الداخلية والخارجية وذلك لتحقيق النجاح بشكل مستمر ـ اما في المستوى العملي يحاول المدير ان يكون حريصا على العمل الجيد وتحليل استخدام المقترحات الجيدة للحفاظ على الاستثمار في الميزة التنافسية . وردت عدة مفاهيم وتعاريف الميزة التنافسية وفق اراء عديدة من الكتاب والباحثين ، لعل اهها يمكن عرضها في الجدول ( 4 ) .

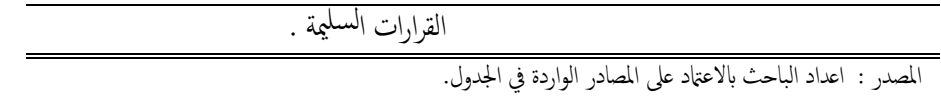
واستنادا الى ماتقدم من تعاريف في الجدول (3) يوضح الباحث بان لنظام المعلومات التسويقية دور مَم في القطاع السياحي باعتبار انه نظام يقدم اهية للمعلومات المتعلقة بنشاطات تسويقية وتحدد على اساس التنؤات الخاصة للسوق و الاستراتيجية التنافسية وهذه المعلومات تكون الاساس والمصدر الرئيسي للنشاطات التسويقية . وكذلك يتحدد مفهوم نظام المعلومات التسويقية من خلال ابعاد وهي : ( kotler et 2000-137) و و(عبدالسلام ابو قفف ، 2001 -141 ) : أ. يتثثل الهدف الجوهري لنظام المعلومات التسويقية ، هو توفير المعلومات الضرورية لادارة التسويق ، ال ان هذه الخصوصية لاتعني حصر هذه الاستفادة في ادارة التسويق فقط ، وانما تعني اولوية ادارة التسويق في الاستفادة من المعلومات التي يوفرها هذا النظام ، مع امكانية استفادة الادارات والمصال الاخرى بالمؤسسة . ب. لتوفير هذه المعلومات لابد من قيام نظام المعلومات التسويقية بتجميع البيانات من المصادر الداخلية والخارجية .

ج· يسامز نظام المعلومات التسويقية من خلال توفير المعلومات الضرورية في تعزيز قدرة الادارة التسويقية على تحقيق جملة من الاهداف كتحديد وتقويم فرص البيع الحمتلة ، الاستجابة السريعة للمتغيرات في الظروف السوقية ، تقرير مستويات الاسعار التي تعظم الربيحة،التحكم في النكاليف التسويقية وصياغة

\section{الاستراتيجيات المستقبلية .}

د. تستلزم ادارة وتشغيل نظام المعلومات التسويقية وجود بموعة من المتطلبات الضرورية التي تتحدد في ضوء دقة وطبيعة المعلومات المعتمدة في تطبيقات هذا

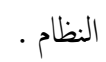
ه. ه - يستمر نظام المعلومات التسويقية باستمرار المؤسسة ، وذلك بتجميع البيانات بطريقة متواصلة بغرض توفير المعلومات في كل الوقات لان الحاجة

$$
\text { اليها غير مستبعدة وغير محددة . }
$$

\subsection{2 اهية نظام المعلومات التسويقية}

ومن اهم النقاط المهمة والجيدة لنظام المعلومات التسويقية هي (ابو علفة، 2002: 25): أ. تحرير وتنظيم التقارير المنظمة والدراسات الجيدة على النشاطات التسويقية . 


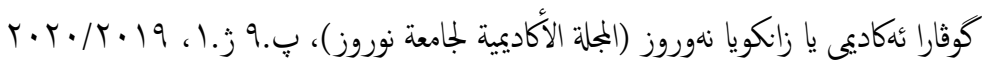

مصادر الميزة التنافسية: ومن اهم المصادرالخاصة بالميزة التنافسية (منير، 2007:

- - المعرفة : اهمية المعرفة في الميزة التنافسية تكون المصدر الرئيسي في

$$
\text { المؤسسة والادارة الناجحة . }
$$

- - الابداع : هو المصدر الرئيسي المتجدد في الميزة التنافسية .

- - الزمن : الوقت يكون من اساسيات الميزة التنافسية في ادارة الانتاج

$$
\text { والخدمات. }
$$

د. عناصر ومكونات الميزة التنافسية: ومن اهم عناصر الميزة التنافسية:

$$
\begin{aligned}
& \text { - زيادة الحصة السوقية للفندق • } \\
& \text { - - تحسين صورة وسمعة الفندق . } \\
& \text { - - } \\
& \text { - - التمييز في الفندق - } \\
& \text { - - توظيف التكنولوجيا الفندقية . } \\
& \text { 3. المور الثالث: الجانب الميداني } \\
& 1.3 \text { وصف استارة الاستبيان }
\end{aligned}
$$

قام الباحث بتطوير الاستبيان لقياس دور نظم المعلومات في دع وتحقيق الميزة

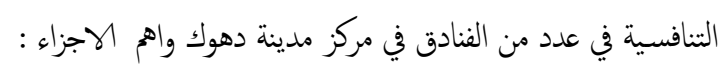

أ. المحور الاول : وتضمن الخصائص الديموغرافية للمبحوثين من حيث الجنس

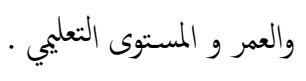

ب. المحور الثاني : يتألف من (35) فقرة ، تقيس مدى توفر عناصر نظام المعلومات التسويقية ( نظام السجلات الساخلية ونظام الاستخبارات التسويقية ونظام بحوث التسويقية و نظام دع القرار ) في فنادق مدينة دهوك و موزعة كما يلي : - الفقرات (10) تقيس مدى توفر نظام السجلات الداخلية لنظام المعلومات

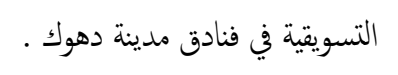

- - الفقرات (10) تقيس مدى توفر نظام الاستخبارات التسويقية لنظام

\begin{tabular}{|c|c|c|c|}
\hline المفهوم او التعريف & السنة و الصفحة & الباحث & ت \\
\hline 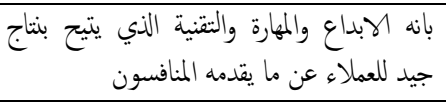 & $102-2001$ & علي السلمي & 1 \\
\hline 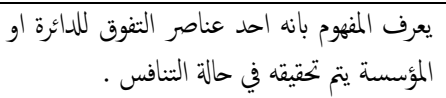 & $37-1998$ & نبيل مرسي & 2 \\
\hline 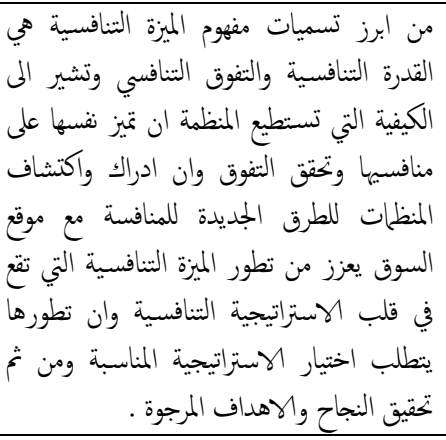 & 18-2012 & فؤاد القاضي & 3 \\
\hline 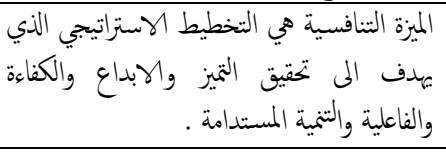 & 77-2011 & | ايمرون سليم و & 4 \\
\hline 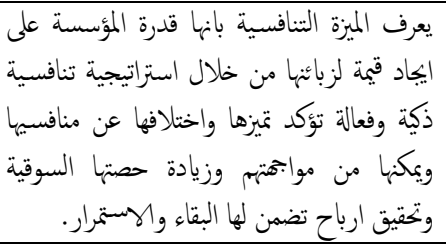 & 193-2010 & 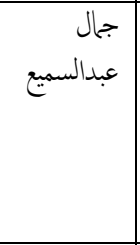 & 5 \\
\hline 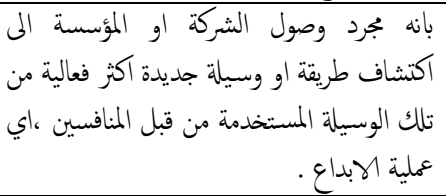 & $48-1993$ & M.Porter & 6 \\
\hline 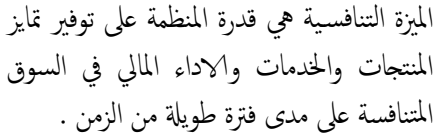 & $12-2015$ & $\begin{array}{r}\text { weier } \\
\text { bach }\end{array}$ & 7 \\
\hline
\end{tabular}

$$
\text { المعلومات التسويقية في فنادق مدينة دهوك . }
$$

ب. خصائص الميزة التنافسية: ومن اهم الخصائص الميزة التنافسية (ححسن، 2009:

$$
\text { - - مكون الميزة التنافسية مستمرة . }
$$

- - تكون الميزة التنافسية بشكل نسبي مقارنة مع المنافسين .

- تميل الميزة التنافسية الى التجديد وفق البيانات للبيئة الخارجية .

- تكون الميزة التنافسية بشكل مرن ، لاستطاعة احلال ميزات اخرى

$$
\text { مكانها بسهولة وفق التغيرات الحاصلة للبيئة . }
$$

- - يجب ان تكون الميزة التنافسية مناسبة مع الطموحات والاهداف والنتائُ

للدائرة او المؤسسة لتحقيقها .

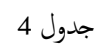

المصدر : اعداد الباحث بالاعتاد على المصادر الواردة في البحث. 


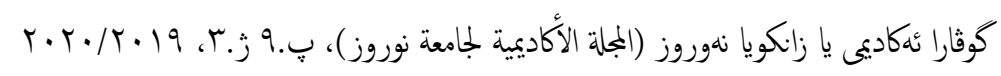

مدينة دهوك ، واثر ذلك على دع وتحيقي الميزة التنافسية في الفادق والوسط الحسابي

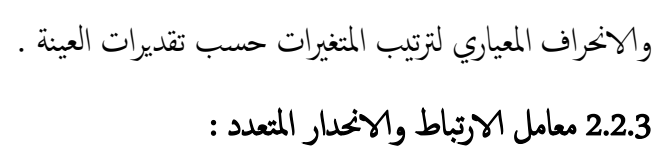

\section{Coefficients Correlation \& Multiple Regression}

لاختبار الفروض الاحصائية الخاصة بتحديد مسهمة نظام المعلومات التسويقية في دع وتحقيق الميزة التنافسية في الفنادق .

أ. مقياس التحليل: كما ذكرنا سابقا ، استخدمت مقياس ليكرت المخاسي لقياس الابعاد المتعلقة باثر نظام المعلومات التسويقية عل الميزة التنافسية ، حيث تم حساب المتوسطات الحسابية لكل الفقرات ، ويين الجدول التالي مقياس

\begin{tabular}{|c|c|}
\hline \multicolumn{2}{|c|}{ مقياس التهليل 5 مل 5} \\
\hline الدرجة & المتوسط الحسابي \\
\hline درجة ايجابية ضعيفة & $2.45-1$ \\
\hline درجة ايجابية متوسطة & $3.49-2.46$ \\
\hline درجة ايجابية عالية & $5-3.50$ \\
\hline
\end{tabular}
التحليل ، الذي تم على اساسه التحليل بناءا على المتوسط الحسابي .

يعرض هذا الجزء النتائُ التي توصلت الهيا الدراسة الميدانية بشأن اختبار صحة الفروض الخاصة بالدراسة ، وسوف يتم ذلك بالنسبة لكل فرض على حدة، وقد تم الاسترشاد بنتأُ التحليل الاحصائي الوصفي (الووساط الحسابية والانحرافات المعيارية ) تتمثل الفروض الرئيسية للبحث گ يلي :

- - الفرض الاول: لا تتوافر عناصر نظام المعلومات التسويقية (السجلات الداخلية والاستخبارات التسويقية وبكوث التسويقية ودع القرار) في فنادق مدينة دهوك . - n

- - الفرض الثاني: لا تتوافر علاقة معنوية ذات دلالة احصائية بين توفر عناصر نظام المعلومات التسويقية (السجلات الداخلية و الاستخبارات التسويقية و بجوث التسويقية ودع القرا) ، ودعز وتحقيق عناصر الميزة التنافسية ( زيادة الحصة السوقية وتحسين وسمعة الفندق وارضاء الزبائن و التميز وتوظيف التكنولوجيا في الفندق ) في فنادق مدينة دهوك. . - م.
- الفقرات (10) تقيس مدى توفر نظام بحوث التسويقية لنظام المعلومات

$$
\text { التسويقية في فنادق مدينة دهوك . - مكرك }
$$

- الفقرات (5) تقيس مدى توفر نظام دع القرار لنظام المعلومات التسويقية

$$
\text { في فنادق مدينة دهوك. }
$$

المحور الثالث : يتألف من (18) فقرة ، تقيس دور عناصر نظام المعلومات $\cdot ?$ التسويقية ( السجلات الناخلية والاستخبارات التسويقية و بحوث التسويقية ودع القرار ) في دع عناصر الميزة التنافسية ( زيادة الحصة السويقية للفندق و تحسين صورة وسمعة الفندق و ارضاء زبائن الفندق والتمييز و توظيف التكنولوجيا الفندقية) في فنادق مدينة دهوك وموزعة كما يلي : - الفقرات (3) تقيس مساهمة نظام المعلومات في دع زيادة الحصة السوقية · للفندق - - الفقرات (4) تقيس مساهمة نظام المعلومات في دع تحسين وسمعة الفندق .

- - - الفقرات (3) تقيس مساهمة نظام المعلومات في دع ارضاء الزبائن في الفندق - - - الفقرات (4) تقيس مساهمة نظام المعلومات في دع توظيف التكنولوجيا

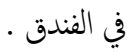
2.3 الاساليب الاحصائية

لقد اعتمد الباحث عند تحليل نتاجُ اجابات عينة الدراسة باستخدام حزمة البرامج الاحصائية الجاهزة ( spss vr - 22 )وكان من اهم الاساليب الاحصائية المناسبة لطبيعة البيانات وفروض الدراسة والتي استخدما الباحث في تحليل البيانات والوصول الى نتائج الدراسة وهي :

Discriptive Statistics : 1.2.3 مقايس الاحصاء الوصفي وذلك لوصف خصائص مجتم الدراسة اعتمادا على التكرارات والنسب المئوية و قد استخدمت للتوصل منهم الى ادراكـ مدى توفر نظام المعلومات التسويقية في فنادق 


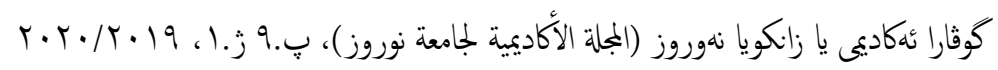

\begin{tabular}{|c|c|c|c|c|}
\hline الدرجة & الترتيب & المعياري & الوسط الحسبي & j \\
\hline عالية & 1 & 0.703 & توفر نظام السجلات الداخلية في نظام 4.193 & 1 \\
\hline عالية & 4 & 1.067 & المعلومات التسويقية المتخبارات في نظام 4.063 & 2 \\
\hline عالية & 3 & 0.973 & توفر نظام بحوث تسويقية في نظام 4.141 & 3 \\
\hline عالية & 2 & 0.907 & التسويقية نظام دع القرار في نظام المعلومات 4.166 & 4 \\
\hline عالية & & 0.912 & نظام المعلومات التسويقية بشكل عام & \\
\hline
\end{tabular}

من الجدول رقز ( 4 ) يبين بان المتوسط العام لفقرات متغير نظام المعلومات التسويقية

كان عاليا ، حيث بلغ (4.141) وهذا يدل على ان تفسيرات الافراد الذين تمت الحصول عليها لمساهمة نظام المعلومات التسويقية في فنادق مدينة دهوك جاءت مرتفعة، حيث احتلت نظام السجلات الداخلية في نظام المعلومات التسويقية على المرتبة الاولى بمتوسط قدره (4.193) ، بينا جاءت نظام دع القرار في نظام المعلومات التسويقية بالمرتبة الثانية بمتوطط قدره ( 4.166) ، وبعدها ثاتي بالمرتبة الثالثة نظام بحوث تسويقية في نظام المعلومات التسويقية بمتوسط قدره (4.141) واخيرا جاءت نظام الاستخبارات التسويقية في نظام المعلومات التسويقية بالمرتبة الرابعة والاخيرة بمتوسط قدره (4.063) .

وتم استخراج المتوسطات الحسابية والانخرافات المعيارية لفقرات مساهمة نظام السجلات الداخلية في النظام المعلومات التسويقية وكما مبين في الجدول (7) : جدول 7

المتوسطات الحسابية والانخرافات المعيارية لنظام السجلات الداخلية في نظام المعلومات التسويقية في فنادق مدينة دهوك . ميك.

\begin{tabular}{|c|c|c|c|c|c|}
\hline الدرجة & الترتيب & المعياري & 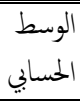 & الفقرات & j \\
\hline عالية & 6 & 0.484 & 4.20 & تيتم تحديث ادارة الفندق بنظام حديث للسجلات & 1 \\
\hline عالية & 4 & 0.583 & 4.27 & 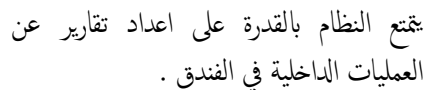 & 2 \\
\hline عالية & 7 & 0.592 & 4.17 & 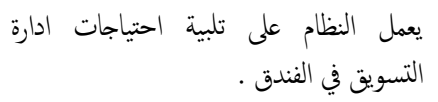 & 3 \\
\hline عالية & 3 & 0.535 & 4.30 & تتميز تقارير نظام السجلات الداخلية بالدقة . . & 4 \\
\hline 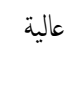 & 2 & 0.809 & 4.37 & الفتيز نظام السجلات الداخلية بالاستجابة & 5 \\
\hline عالية & 3 & 0.877 & 4.30 & تعزيز استخدام نظام الاجززة المستخدمة التي تساهم في & 6 \\
\hline عالية & 8 & 0.885 & 4.10 & تتميز البرامج والاتهزة المستخدمة في نظام & 7 \\
\hline
\end{tabular}

وينقسم هذا الفرض الرئسي الى الفروض الفرعية التالية :

لا توجد علاقة معنوية ذات دلالة احصائية بين متغيرات عناصر نظام المعلومات

التسويقية (السجلات الداخلية و الاستخبارات التسويقية و بحوث التسويقية ودعز القرار ) وتحقيق زيادة الحصة السوقية في فنادق مدينة دهوك .

لا توجد علاقة معنوية ذات دلالة احصائية بين متغيرات عناصر نظام المعلومات التسويقية (السجلات الداخلية و الاستخبارات التسويقية و بحوث التسويقية ودعز القرار ) وتحقيق تحسين صورة وسمعة الفندق ، في فنادق مدينة

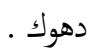

لا توجد علاقة معنوية ذات دلالة احصائية بين متغيرات عناصر نظام المعلومات التسويقية (السجلات الداخلية و الاستخبارات التسويقية و بحوث التسويقية ودعز القرار ) وتحقيق ارضاء الزبائن في فنادق مدينة دهوك . لا توجد علاقة معنوية ذات دلالة احصائية بين متغيرات عناصر نظام المعلومات التسويقية (السجلات الداخلية و الاستخبارات التسويقية و بحوث التسويقية ودعز القرار ) وتحقيق التميز في فنادق مدينة دهوك . لا توجد علاقة معنوية ذات دلالة احصائية بين متغيرات عناصر نظام المعلومات التسويقية (السجلات الداخلية و الاستخبارات التسويقية و بحوث التسويقية ودعز القرار ) وتحقيق توظيف التكنولوجيا الفندقية ، في فنادق مدينة دهوك . 1.3.3 نتائج اختبار الفرض الوول وحسن توطي

الفرض العدم (H0) : لا تتوافر عناصر نظام المعلومات التسويقية (السجلات الداخلية والاستخبارات التسويقية و بحوث التسويقية ودع القرار ) ، في فنادق مدينة دهوك . - م ك.

الفرض البديل (H1) : تتوافر عناصر نظام المعلومات التسويقية (السجلات الداخلية والاستخبارات التسويقية و بحوث التسويقية ودع القرار )، في فنادق

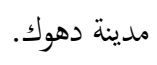
يوضح الجدول (6) المتوسطات الحسابية والانحرافات المعيارية لاجابات افراد العينة عن مدى توافر نظام المعلومات التسويقية في فنادق مدينة دهوكك. جدول 6

المتوسطات الحسابية والانرافات المعيارية لنظام المعلومات التسويقية في فنادق مدينة دهوك . 


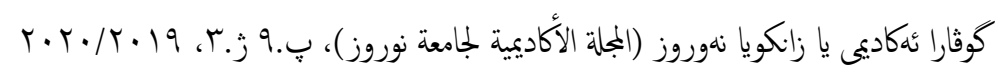

بالمرتبة التاسعة والاخيرة الفقرة (9) والتي تنص على (يتم تدريب العاملين في الفندق

في قسم التسويق على استخدام نظام السجلات الداخلية بكفاءة) بمتوسط حسابي

(3.93) وانخراف معياري (0.868) ـ وبلغ المتوسط الحسابي العام لسجلات الداخلية

(4.193) وبانحراف معياري (0.703) كانت بدرجة عالية ، اي ان تصورات الافراد

عن مساهمة نظام السجلات الداخلية في نظام المعلومات التسويقية في فنادق مدينة

دهوك جاءت مرتفعة ـ وتبين للباحث من خلال الوسط الحسابي للفقرة (9) بان

تدريب العاملين بنظام السجلات الداخلية للفندق في قسم التسويق على استخدام

نظام السجلات الداخلية بكفاءة ، كانت اقل استخداما مقارنة بباقي الانشطة

التسويقية التي تقوك بها السجلات الداخلية في فنادق مدينة دهوك ـ وهذا قد يؤدي

$$
\text { الى فقدان بعض الفرص التسويقية . }
$$

وكذلك تم استخراج المتوسطات الحسابية والانحرافات المعيارية لفقرات نظام

الاستخبارات التسويقية في نظام المعلومات التسويقية وكما في الجدول(8) :

جدول 8

المتوسطات الحسابية والاخرافات المعيارية لفترات نظام الاستخبارات التسويقية في نظام المعلومات

التسويقية .

\begin{tabular}{|c|c|c|c|c|}
\hline الدرجة & التزتيب & المعياري & 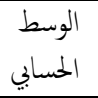 & الفقرات \\
\hline عالية & 4 & 1.081 & 4.07 & الفنادق تجع المنافسة ب بصورة دورية المعلمات عن \\
\hline عالية & 7 & 1.159 & 3.97 & 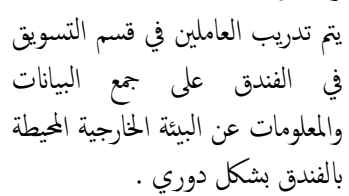 \\
\hline عالية & 5 & 1.066 & 4.03 & 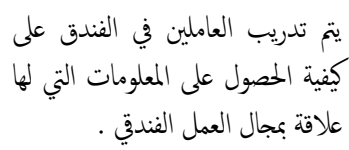 \\
\hline عالية & 5 & 0.765 & 4.03 & 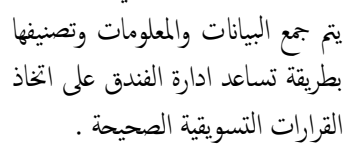 \\
\hline عالية & 2 & 1.033 & 4.37 & يمكن استغلالهام في السوق المستهدف التي \\
\hline عالية & 1 & 0.968 & 4.40 & تتبتعها الفنادق النظام الاستراتيجيات التي \\
\hline عالية & 3 & 1.224 & 4.13 & 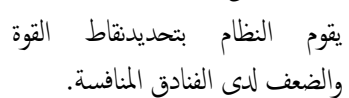 \\
\hline عالية & 8 & 1.143 & 3.93 & حينباً النظام بردة فعل الفنادق المنافسة \\
\hline
\end{tabular}

السجلات الداخلية بالسرعة الكلفية في عملية

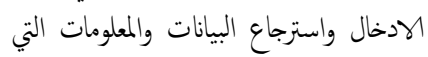
تمتاجما ادارة الفندق .

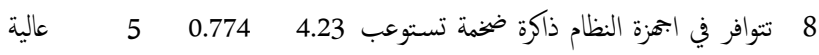

جميم البيانات والمعلومات الفندقية والقدرة على الفي

الحفظ

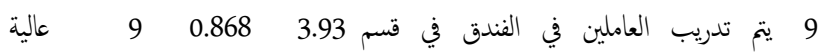

التسويق على استخدام نظام السجلات

الداخلية بكفاءة .

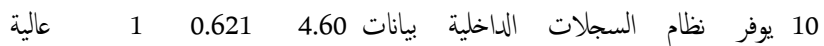

ومعلومات كفية عن البيئة التي تتعامل معها لإلية

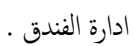

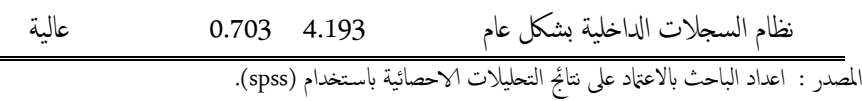

من الجدول ( 7 ) يبين بان الفقرة (10) والتي تنص على (يوفر نظام السجلات الداخلية بيانات ومعلومات كافية عن البيئة التي تتعامل معها ادارة الفندق) في المرتبة

الاولى بمتوسط حسابي (4.60) وانخراف معياري(0.62) وبعدها تاتي في المرتبة الثانية ، الفترة (5) والتي تنص على (يتميز نظام السجلات الداخلية بالاستجابة الفورية) بمتوسط حسابي (4.37) وانحراف معياري(0.809) ، وفي المرتبة الثالثة تاتي الفقتين (4 ، 6 ) والتي تنصان على (تتميز تقارير نظام السجلات الداخلية بالدقة • و يتم تحديث الاجهزة المستخدمة التي تساهم في تعزيز استخدام نظام السجلات الداخلية ) بمتوسط حسابي (4.30 ) و انخرافين معياريين ( 0.535 و 0.877 ) ، وتلنها في المرتبة الرابعة الفقرة (2) والتي تنص على (يتتع النظام بالقدرة على اعداد تقارير عن العمليات الداخلية في الفندق ) بمتوسط حسابي (4.27 ) وانحراف معياري (0.583) ، وكذلك تاتي في المرتبة الخامة الفقرة (8) ونصها (تتوافر في اجهزة النظام ذاكرة ضخمة تستوعب حجم البيانات والمعلومات الفندقية والقدرة على الحفظ ) بمتوسط حسابي (4.23) وانخراف معياري (0.774) ، بينا جاءت الفقرة (1) بالمرتبة السادسة والتي تنص على (تحتفظ ادارة الفندق بنظام حديث للسجلات يتم تحديثه باستمرار) بمتوسط حسابي (4.20) وانحراف معياري (0.484) و ياتي الفقرة (3) بالمرتبة السابعة والتي تنص على (يعمل النظام على تلبية احتياجات ادارة التسويق في الفندق) بمتوسط حسابي (4.17) وانحراف معياري (0.592) ، وتلنها الفقرة (7) بالمرتبة الثامنة والتي تنص على (تتميز البرامج والاجهزة المستخدمة في نظام السجلات الداخلية بالسرعة الكلفية في عملية الادخال واسترجاع البيانات والمعلومات التي تتناجما ادارة الفندق) بمتوسط حسابي (4.10) وانخراف معياري (0.885) ، واخيرا جاءت 


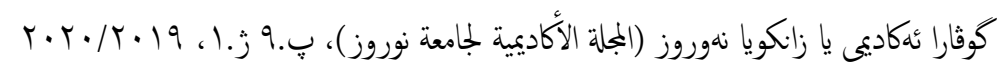

وبلغ المتوسط الحسابي العام للاستخبارات التسويقية بمتوسط حسابي (4.063) وانحراف معياري ( 1.067) . وتبين للباحث من خلال الاوساط الحسابية للفقرات (2 ، 8 ، 10) ان عملية جمع البيامات والمعلومات عن البيئة الخارجية المحيطة بالفندق وكذلك تنبؤ النظام بردة فعل الفنادق المنافسة حول العمليات والاجراءات الفندقية والتنويع بالوسائل للحصول على البيانات الخاصة بالفنادق المنافسة كانت اقل استخداما مقارنة بباقي الانشطة التسويقية التي تقوم بها الاستخبارات التسويقية في الفنادق في مدينة دهوك ، وهذا يؤدي الى فقدان بعض الفرص التسويقية وكذلك موابجة بعض المخاطر نتيجة عدم الاطلاع الدائم على البيئة التسويقية . وكذلك تم استخراج الاوسط الحسابية والاخرافات المعيارية لفقرات نظام البحوث التسويقية في نظام المعلومات التسويقية ،كما مبين في الجدول (9) :

$$
\text { جدول } 9
$$

الاوساط الحسابية والانحرافات المعيارية لبحوث التسويقية في نظام المعلومات

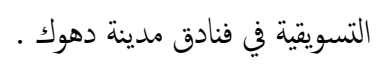

\begin{tabular}{|c|c|c|c|c|}
\hline الدرجة & التزتيب & المعياري & 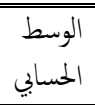 & الفقرات \\
\hline عالية & 6 & 0.999 & 4.03 & 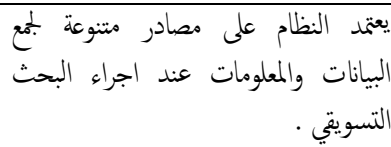 \\
\hline عالية & 6 & 1.129 & 4.03 & 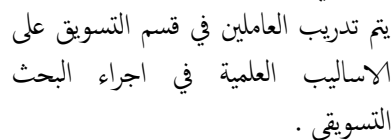 \\
\hline عالية & 1 & 0.498 & 4.60 & لاحتياجات الفندق البحوث التسويقية وفقا \\
\hline عالية & 7 & 1.048 & 3.93 & البحث والتسويتي. وتحديد جدول زمني لاجراء \\
\hline عالية & 3 & 0.868 & 4.27 & 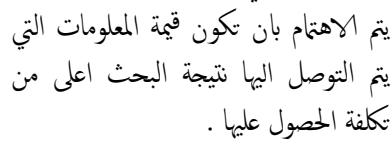 \\
\hline عالية & 4 & 0.935 & 4.23 & التسويتي. . توخي الدقة في عملية اجراء البحث \\
\hline عالية & 7 & 1.048 & 3.93 & 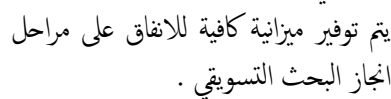 \\
\hline عالية & 7 & 1.143 & 3.93 & 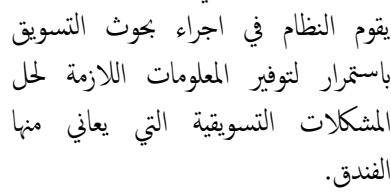 \\
\hline عالية & 2 & 0.959 & 4.33 & تيتم تدريب العاملين في بحوث التسويق على الدئ \\
\hline عالية & 5 & 1.106 & 4.13 & 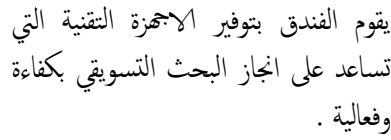 \\
\hline
\end{tabular}

\begin{tabular}{|c|c|c|c|c|}
\hline عالية & 6 & 1.050 & 4.00 & اوضاع السوق الفندقية بصورة دقيقة النقاري دقيقة عند \\
\hline عالية & 9 & 1.179 & 3.70 & 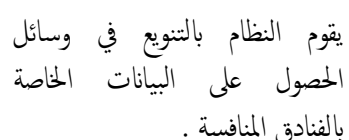 \\
\hline عالية & & 1.067 & 4.063 & نظام الاستخبارات التسويقية بشكل \\
\hline
\end{tabular}

المصدر : اعداد الباحث بالاعتاد على ننائُ النحليلات الاحصائية باستخدام (spss). من الجدول ( 8 ) ييين بان الفقرة (6) والتي تنص على (يتابع النظام الاستراتيجيات التي تتبعها الفنادق المنافسة) احتلت المرتبة الاولى بمتوسط حسابي (4.40) وانحراف معياري (0.968) ، وتلتها في المرتبة الثانية ، الفقرة (5) والتي تنص على (يساعد النظام على تحديد الفرص التي يمكن استغلالها في السوق المستهدف) بمتوسط حسابي (4.37) وانخراف معياري (1.033) ، وفي المرتبة الثالثة جاءت الفقرة (7) والتي تنص على (يقوم النظام بتحديدنقاط القوة والضعف لدى الفنادق المنافسة) بمتوسط حسابي (4.13) وانحراف معياري (1.224) ، وبعدها جاءت بالمرتبة الرابعة ، الفقرة (1) والتي تنص على (يتم جمع البيانات والمعلومات عن الفنادق المنافسة بصورة دورية ومستمرة) بمتوسط حسابي (4.07) وانحراف معياري (1.08) ، ببنا بالمرتبة الخامسة جاءت الفقرتين ( 3 و4 ) والتي تنصان على (يتم تدريب العاملين في الفندق على كيفية الحصول على المعلومات التي لها علاقة بمجال العمل الفندقي و يتم جمع البيانات والمعلومات وتصنيفها بطريقة تساعد ادارة الفندق على اتخاذ القرارات التسويقة الصحيحة) بمتوسط حسابي (4.03) و انحرافين معياريين ( , 0.765 1.066) ، وتليها بالمرتبة السادسة الفقرة (9) والتي تنص على (يزود النظام الفندق بتقارير دقيقة عن اوضاع السوق الفندقية بصورة دقيقة ) بمتوسط حسابي (4.00) وانحراف معياري (1.050) ، وتليها تاتي الفقرة (2) بالمرتبة السابعة والتي تنص على (يتم تدريب العاملين في قسم التسويق في الفندق على جمع البيانات والمعلومات عن البيئة الخارجية المحيطة بالفندق بشكل دوري ) بمتوسط حسابي ( 3.97) وانخراف معياري ( 1.159) ، وتاتي بالمرتبة الثامنة الفقرة ( 8) والتي تنص على (يتنباً النظام بردة فعل الفنادق المنافسة حول العمليات والاجراءات الفندقية ) بمتوسط حسابي 9 (3.93) وانخراف معياري ( 1.143) واخيرا احتلت الفترة (10) المرتبة العاشرة والاخيرة والتي تنص على (يقوم النظام بالتنويع في وسائل الحصول على البيانات الخاصة بالفنادق المنافسة ) بمتوسط حسابي ( 3.70) وانحراف معياري ( 1.179) . 


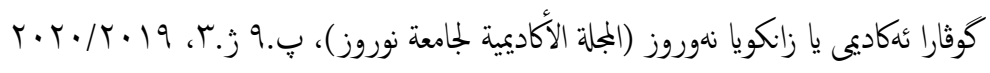

\begin{tabular}{|c|c|c|c|c|}
\hline & & & & 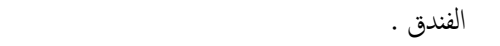 \\
\hline 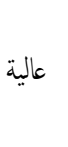 & 1 & 0.900 & 4.47 & 2 تلساعد نظام دع القرار في المعالجة الاحصائية \\
\hline 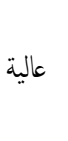 & 2 & 0.794 & 4.30 & 3 تساعد نظام دع القرار في تحقيق الدقة والسرعة في \\
\hline عالية ل & 5 & 0.950 & 3.83 & 4 على المعلومات اللازمة دعة القرار على الحاسوب في القرار في الفندق . \\
\hline 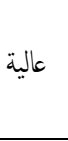 & 4 & 1.029 & 4.10 & 5 يساعد لستخدام نظام دعز القرار في العملية \\
\hline عالية & & 0.907 & 4.166 & نظام دع القرار بشكل عام \\
\hline
\end{tabular}

ومن الجدول ( 10 ) اعلاه تبين بان الفقرة (2) احتلت المرتبة الاولى والتي تنص على على

(تساعد نظام دع القرار في المعالجة الاحصائية للبيانات التسويقية التي تؤثر في النشاط التسويتي للفندق ) بمتوسط حسابي (4.47) وانخراف معياري (0.900) ،وتليها في المرتبة الثانية الفقرة(3) والتي تنص على (تساعد نظام دع القرار في تحقيق الدقة والسرعة في اتخاذ القرار الاستراتيجي الذي يخص مستقبل الفندق ) بمتوسط حسابي (4.30) وانخراف معياري (0.794) ،بينا جاءت بالمرتبة الثالثة الفقرة(1) والتي تنص على (تعتبر نظام دع القرار مكملا لنظام المعلومات التسويقية والبيانات اللازمة لحل المشكلات في الفندق ) بمتوسط حسابي (4.13) وانحراف معياري (0.860) ، وبعدها جاءت بالمرتبة الرابعة الفقرة ( 5) والتي تنص على (يساعد لستخدام نظام دع القرار في العملية التسويقية عل حل المشاكل غير الروتينية في الفندق ) بمتوسط حسابي ( 4.10) وانخرافه المعياري ( 1.029) واخيرا جاءت الفقرة (4) بالمرتبة الخامسة والاخيرة والتي تنص على (تعمد نظام دع القرار على الحاسوب في الحصول على المعلومات اللازمة لمتخذي القرار في الفندق ) بمتوسط حسابي (3.83) وانحرافه المعياري (0.950) . وبلغ المتوسط العام لدع القرار (4.166)

وانخرافه المعياري ( 0.907 ) . 2.3.3 نتاجُ اختبار الفرض الثاني - - الفرض العدم (H0): لا توجد علاقة معنوية ذات دلالة احصائية بين توفر عناصر نظام المعلومات التسويقية (السجلات الداخلية، الاستخبارات التسويقية ، البحوث التسويقية و دع القرار) و دع وتحقيق عناصر الميزة

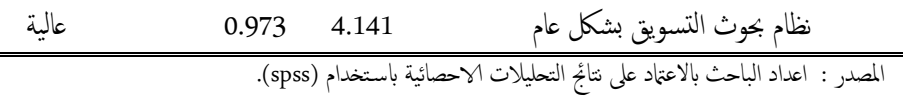

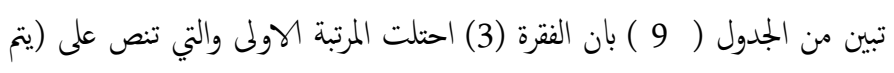
اجراء البحوث التسويقية وفقا لاحتياجات الفندق كبتوسط حسابي (4.60) وانحراف معياري (0.498) ، وتليها في المرتبة الثانية الفقرة (9) والتي تنص على (يتم تدريب العاملين في بحوث التسويق على توخي الدقة عند اجرائه ) بمتوسط حسابي (4.33) وانخراف معياري ( 0.959) ، بينا تاتي في المرتبة الثالثة الفقرة(5) والتي تنص (يتم الاهتام بان تكون قيمة المعلومات التي يتم التوصل الهيا نتيجة البحث اعلى من نكلفة الحصول عليها ) بمتوسط حسابي (4.27) وانخراف معياري (0.868) واحتلت الفقرة (6) المرتبة الرابعة والتي تنص على (يتم توخي الدقة في عملية اجراء البحث التسويقي) بمتوسط حسابي (4.23) وانحراف معياري (0.935) وتليها الفقرة(10) بالمرتبة الخامسة والتي تنص على (يقوم الفندق بتوفير الاجهزة التقنية التي تساعد على انجاز البحث التسويتي بكفاءة وفعالية) بمتوسط حسابي (4.13) وانحراف معياري (1.106) ، والفترتين ( 1 ، 2 ) احتلنا المرتبة السادسة والتي تنصان على (يعتمد النظام على مصادر متنوعة لجمع البيانات والمعلومات عند اجراء البحث التسويتي و يتم تدريب العاملين في قسم التسويق على الاساليب العلمية في اجراء البحث التسويقي ) بمتوسط حسايي (4.03) وانحرافين معياريين ( 0.999 , 1.129) وتليها في المرتبة السابعة والاخيرة الفترات (4 ، 7 ، 8 ) والتي تنص على (يتم وضع وتحديد جدول زمني لاجراء البحث التسويقي و يتم توفير ميزانية كافية للانفاق على مراحل انجاز البحث التسويقي و يقوم النظام في اجراء بحوث التسويق باستمرار لتوفير المعلومات اللازمة لحل المشكلات التسويقة التي يعاني منها الفندق ) بمتوسط حسابي (3.93) وانحراف معياري ( 1.048 , 1.048 , 1.143) على التوالي • وبلغ المتوسط العام لبحوث التسويق (4.141) وانحرافه المعياري (0.973) . وكذلك تم استخراج الاوساط الحسابية والانخرافات المعيارية لفقرات نظام دع القرار في نظام المعلومات التسويقية وكمافي الجدول (10) : جدول 10

المتوسطات الحسابية والاخرافات المعيارية لدع القرار في نظام المعلومات التسويقية في فنادق مدينة

\begin{tabular}{|c|c|c|c|c|}
\hline \multicolumn{5}{|r|}{ دهوك } \\
\hline الدرجة & لترتيب & المعياري & 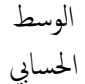 & ــ الفقرات \\
\hline عالية & 3 & 0.860 & 4.13 & 1 التعبور نظام دوع القرار مكملا لنظام المعلومات \\
\hline
\end{tabular}




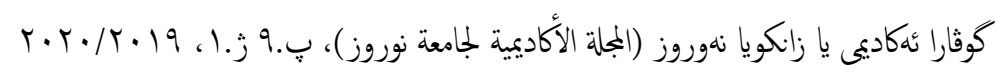

الاوساط الحسابية والاخرافات المعيارية لزيادة الحصة السوقية للفندق في الميزة التنافسية لفنادق

\begin{tabular}{|c|c|c|c|}
\hline \multicolumn{4}{|c|}{ مدينة دهوك } \\
\hline التزتيب الدرجة & المسابي المعياري المخراف & الفقرات & j \\
\hline
\end{tabular}

تهتم ادارة الفندق بزيادة حصتها السوقية الفندقية

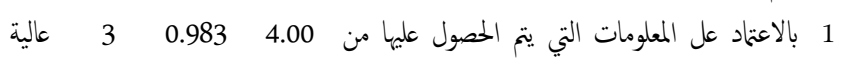

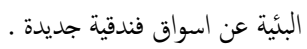

تهتم ادارة الفندق بزيادة حصتها السوقية الفندقية

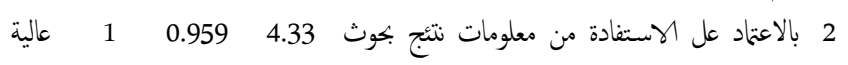

التسويق لتقديم خدمات فندقية جديدة .

تهتم ادارة الفندق بزيادة حصتها السوقية الفندقية

3 بالاعتاد عل الاستفادة من المعلومات لزيادة 14.27

الخدمات الفندقية الحالية.

زيادة الحصة السوقية للفندق بشكل عام. المصدر : اعداد الباحث بالاعتاد على ننأُ التعليلات الوحصائية باستخدام (spss).

من الجدول ( 12 ) اعلاه تبين بان الووساط الحسابية لاجابات افراد العينة كانت بين

$$
(4.00-4.33)
$$

اعلاها الفقرة (2) والتي تنص على (تهتم ادارة الفندق بزيادة حصتها السوقية الفندقية بالاعتماد عل الاستفادة من معلومات نتئج بحوث التسويق لتقديم خدمات فندقية جديدة ) ، بينا كانت ادناه الفقرة (1) والتي تنص على (تهتم ادارة الفندق بزيادة حصنها السوقية الفندقية بالاعتاد عل المعلومات التي يتم الحصول عليها من البئية عن

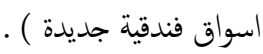

وكذلك كانت الاجابات عن فقرات تحسين صورة وسمعة الفندق في الميزة التنافسية

في فنادق مدينة دهوك كمافي الجدول(13) :

جدول 13

الاوساط الحسابية والاخرافات المعيارية لتحسين صورة وسمعة الفندق في الميزة التنافسية في فنادق

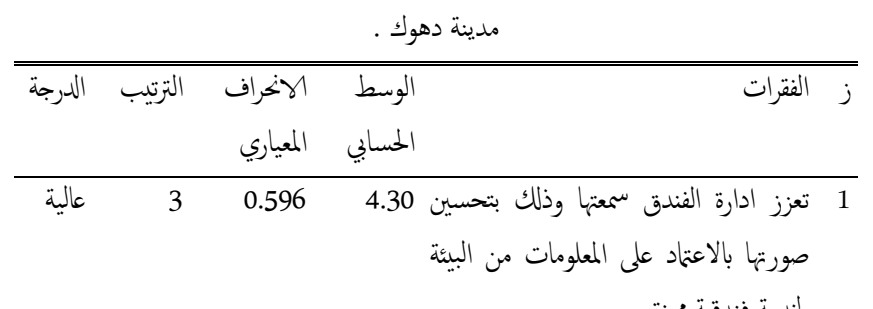

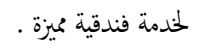

2 تعزز ادارة الفندق سمعتها وذلك بتحسين $4.43 \quad 0.817 \quad 2 \quad 2$

صورتها بالاعتماد على قواعد بيانات الزبائن

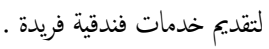

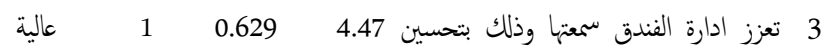

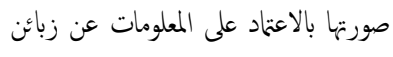

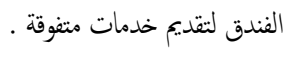

التنافسية ( زيادة الحصة السوقية ، تحسين صورة وسمعة الفندق، ارضاء زائن الفندق، التميز وتوظيف التكنولوجيا الفندقية ) في فنادق مدينة دهوك.

- - الفرض البديل (H1): توجد علاقة معنوية ذات دلالة احصائية بين توفر عناصر نظام المعلومات التسويقية ( السجلات الداخلية ، الاستخبارات التسويقية ، البحوث التسويقية و دع القرار) و دع وتحقيق عناصر الميزة التنافسية ( زيادة الحصة السوقية ، تحسين صورة وسمعة الفندق، ارضاء زائن الفندق، التميز وتوظيف التكنولوجيا الفندقية ) في فنادق مدينة دهوك. - - - مفيميلي توضيح للاوساط الحسابية والاخرافات المعيارية لاجابات وتصورات افراد العينة عن دع ومساهمة الفقرات التسويقية لتحقيق الميزة التنافسية في - - - منادق مدينة دهوك وكما مبين في الجدول (11):

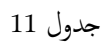
الاوساط الحسابية والاخرافات المعيارية لمساهمة الفقرات التسويقية في دع وتحقيق الميزة التنافسية

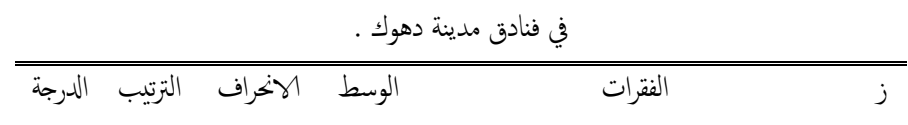

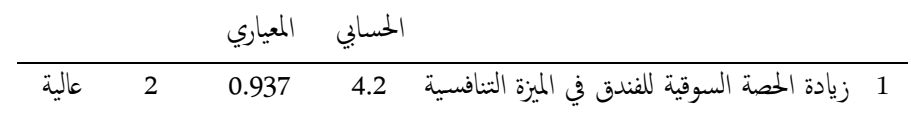

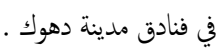

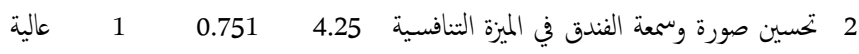

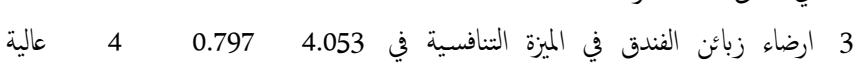

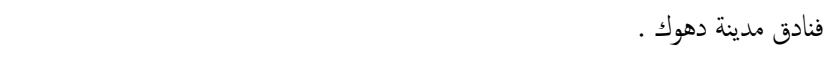
4 التميز في الميزة التنافسية في فنادق مدينة دهوك.

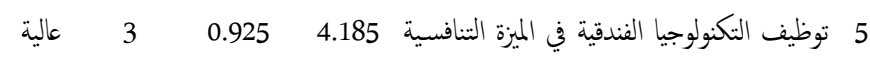
الميزة الننافسية في فنادق مدينة دهوك المصدر : اعداد الباحث بالإعناد على نتائُ التحليلات الوحصائية باستخدام (spss).

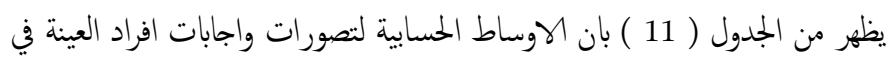
الميزة التنافسية تتزاوح بين (4.05 - 4.25) اعلاه للفقرة الثانية التي تنص على (تحسين صورة وسمعة الفنادق ) و ادناه تكون للفقرة (ارضاء الزبائن ) وبلغ الوسط الحسابي العام للميزة التنافسية (4.174) وجاءت مرتفعة . وفيميلي عرض للاوساط الحسابيةوالانحرافات المعيارية عن كل فقرات الحصة السوقية للميزة التنافسية في فنادق مدينة دهوك، كما مبين في الجدول (12) :

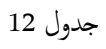




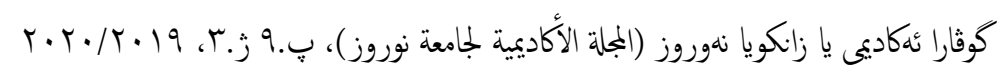

ومن الجدول ( 14 ) تبين بان الهوساط الحسابية تتراوح بين (3.60 - 4.43) ،

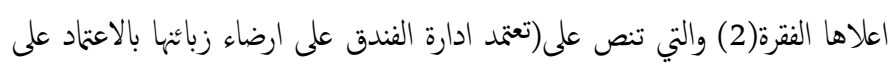
المعلومات من اجل تقديم خدمة فندقية افضل) و ادناه كانت الفقرة(1) والتي تنص على(تعمد ادارة الفندق على ارضاء زباتيها بالاعتمد على المعلومات عن الفنادق المنافسة من اجل تقديم خدمات فندقية باقل الاسعار ) . ونلاحظ بان اعتاد ادارة الفندق على المعلومات من الفنادق المنافسة لارضاء زبائها كانت اقل من باقي الفقرات وذلك حسب قلة الوسط الحسابي للفقرة المذكورة . وبعدها تمت استخراج الووساط الحسابية والانحرافات المعيارية لفقرات التميز في الميزة التنافسية في فنادق مدينة دهوك وكما في الجدول(15) :

جدول 15

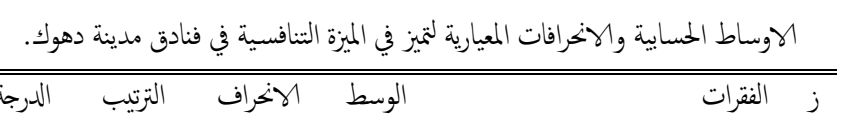
الحسابي المعياري

\begin{tabular}{|c|c|c|c|c|c|}
\hline عالية & 1 & 0.621 & 4.40 & 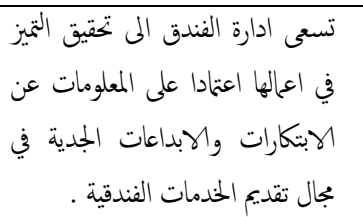 & 1 \\
\hline عالية & 2 & 0.868 & 4.27 & 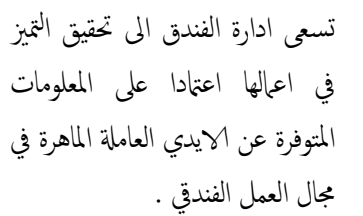 & 2 \\
\hline عالية & 4 & 0.999 & 3.97 & 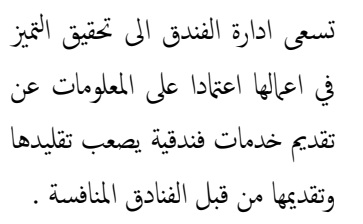 & 3 \\
\hline عالية & 3 & 0.923 & 4.10 & 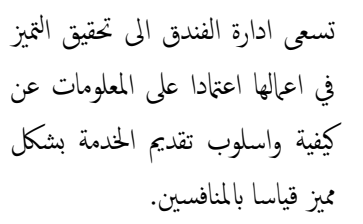 & 4 \\
\hline عالية & & & 4.185 & التميز في الميزة التنافسية بشكل عام & \\
\hline
\end{tabular}

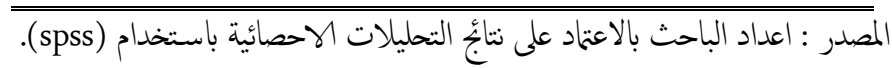
تبين من الجدول ( 15 ) بان الفقرة(1) احتلت المرتبة الاولى والتي تنص على (تسعى ادارة الفندق الى تحقيق التميز في اعالها اعتمادا على المعلومات عن الابتكارات والابداعات الجدية في مجال تقديم الخدمات الفندقية ) بمتوسط حسابي (4.40) زانحراف معياري (0.62) وتليها بالمرتبة الثانية الفقرة (2) والتي تنص على (تسعى ادارة

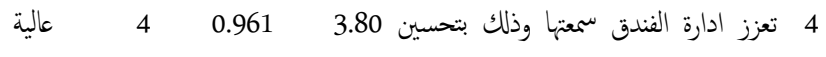

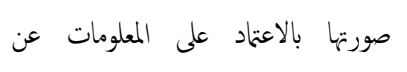

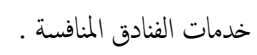

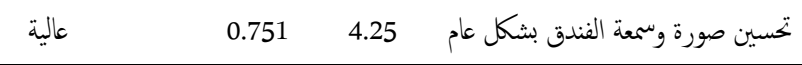
المصدر : عداد الباحث بالاعتلاد على نتانج التحليلات الوحصائية باستخدام (spss). من الجدول (13 ) تبين بان الفقرة (3) احتلت المرتبة الوولى والتي تنص على (تعزز ادارة الفندق سمعتها وذلك بتحسين صورتها بالاعتماد على المعلومات عن زبائن الفندق لتقديم خدمات متفوقة ) بمتوسط حسابي (4.47) وتليها الفقرة (2) والتي تنص على (تعزز ادارة الفندق سمعتها وذلك بتحسين صورتها بالاعتماد على قواعد بيانات الزبائن لتقديم خدمات فندقية فريدة )جاءت بالمرتبة الثانية بمتوسط حسابي (4.43) بينا جاءت بالمرتبة الثالثة الفقرة(1) والتي تنص على(تعزز ادارة الفندق سمعتها وذلك بتحسين صورتها بالاعتماد على المعلومات من البيئة لخدمة فندقية مميزة ) بمتوسط حسابي (4.30) واخيرا جاءت الفقرة (4) بالمرتبة الربعة والالاخيرة والتي تنص على(تعزز ادارة الفندق سمعتها وذلك بتحسين صورتها بالاعتاد على المعلومات عن

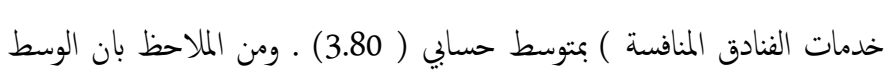
الحسابي للفقرة (4) اقل من باقي الفقرات وهذا يدل على ان استخدام المعلومات من الفنادق المنافسة كانت اقل من باقي الفقرات لتحسين صورة وسمعة الفندق . وبعد ذلك تمت استخراج الاوساط الحسابية والانرافات المعيارية لفقرات ارضاء الزبائن في الفندق في الميزة التنافسية في فنادق مدينة دهوك وكمافي الجدول(14) : جدول 14

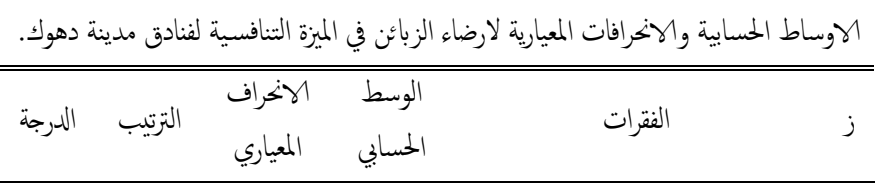

\begin{tabular}{|c|c|c|c|c|c|}
\hline عالية & 3 & 0.932 & 3.60 & 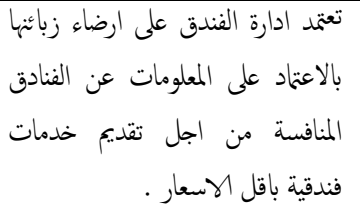 & 1 \\
\hline عالية & 1 & 0.728 & 4.43 & 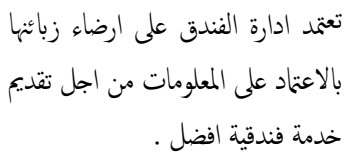 & 2 \\
\hline عالية & 2 & 0730 & 4.13 & تبتمد ادارة الفندق على ارضاء زبائها & 3 \\
\hline عالية & & 0.797 & 4.053 & 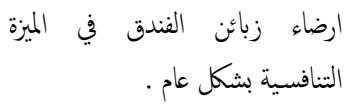 & \\
\hline
\end{tabular}

المصدر : اعداد الباحث بالاعتماد على نناجُ التحليلات الاحصائية باستخدام (spss). 


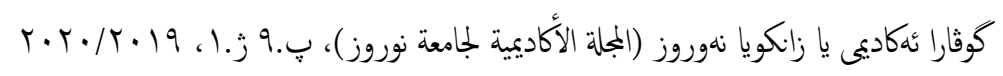

من الجدول( 16 ) اعلاه تبين بان الووساط الحسابية تتراوح بين ( 3.97 - 4.30)، اعلاها للفقرات (2 ، 4 ) والتي تنصان على (تثفوق ادارة فندقكم عن الفنادق المنافسة في توظيف التكنولوجيا اعتمادا على معلومات عن نظام الحاسوب الالي المعمول به في الفندق و المعلومات المتاحة عن قواعد المعرفة للفنادق المتاحة ) ، بينلا ادناه الفقرة(3) والتي تنص على (تثفوق ادارة فندقكم عن الفنادق المنافسة في توظيف التكنولوجيا اعتلادا على المعلومات عن اسلوب تقديم الخدمة الفندقية بشكل متميز مقارنة مع

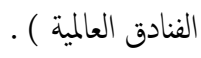

الجدول التالي يوضح العلاقة بين نظم المعلومات التسويقية ودع وتحقيق المزايا التنافسية لفنادق مدينة دهوك، و ذلك باستخدام معامل ارتباط بيرسونكما في الجدول

جدول 17

تبين العلاقة بين نظم المعلومات التسويقية ودع وتحيق الميزة التنافسية لفادق مدينة دهوك :

\begin{tabular}{|c|c|c|c|c|c|c|}
\hline \multirow{4}{*}{ التوظنيف } & \multirow[t]{4}{*}{ التميز } & \multirow{2}{*}{ زارضاء } & \multirow{2}{*}{ صورة } & \multirow{2}{*}{ زيادة } & \multicolumn{2}{|r|}{ |الميزة } \\
\hline & & & & & & \\
\hline & & الفندق & وسمعة & السوقية & & \\
\hline & & & الفندق & اللفندق & & \\
\hline$-0.429^{*}$ & 0.127 & -0.165 & 0.067 & 0.316 & معامل الارتباط & \\
\hline 0.018 & 0.505 & 0.383 & 0.725 & 0.089 & الدلالة|الحصائية & \\
\hline 30 & 30 & 30 & 30 & 30 & العدد & \\
\hline 0.327 & 0.219 & 0.361 & 0.202 & 0.125 & معامل الارتباط & \\
\hline 0.078 & 0.245 & 0.050 & 0.285 & 0.509 & الدلالة|احصائية & خستخبارات \\
\hline 30 & 30 & 30 & 30 & 30 & العدد & \\
\hline 0.008 & 0.137 & 0.151 & -0.005 & -0.061 & معامل الارتباط & \\
\hline 0.966 & 0.472 & 0.426 & 0.981 & 0.748 & الدلالة|احصائية & \\
\hline 30 & 30 & 30 & 30 & 30 & العدد & التسويق \\
\hline-0.146 & 0.029 & -0.277 & -0.009 & $0.365^{*}$ & معامل الارتباط & تطام \\
\hline 0.442 & 0.087 & 0.138 & 0.964 & 0.048 & الدلالة|الاحصائية & دק \\
\hline 30 & 30 & 30 & 30 & 30 & العدد & قرار \\
\hline
\end{tabular}

المصدر : اعداد الباحث بالاعتاد على نتائج التهليلات الوحصائية باستخدام spss.

تبين من الجدول (17) وجود علاقة تأثير ايجابية ذات دلالة احصائية(0.005 ك ة)، بين السجلات الداخلية وتوظيف التكنولوجيا الفندقية و بين الاستخبارات التسويقية ورضا الزبائن و بين نظام دع القرار و زيادة الحصة السوقية. ونلاحظ بان اعلى درجات الارتباط بين السجلات الداخلية و توظيف التكنولوجيا الفندقية وبدرجة

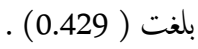

الفندق الى تحتيق التميز في اعلالها اعتمادا على المعلومات المتوفرة عن الايدي العاملة الماهرة في مجال العمل الفندقي ) بمتوسط حسابي (4.27) وانخراف معياري (0.868)، بينما في المرتبة الثالثة تاتي الفقرة (4) والتي تنص على (تسعى ادارة الفندق الى تحقيق التميز في اعالها اعتمادا على المعلومات عن كيفية واسلوب تقديم المدمة بشكل ميز قياسا بالمنافسين ) بمتوسط حسابي (4.10) وانحراف معياري (0.923) واخيرا تاتي الفقرة (3) بالمرتبة الرابعة والاخيرة والتي تنص على (تسعى ادارة الفندق الى تحتيق التميز في اعالها اعتمادا على المعلومات عن تقديم خدمات فندقية يصعب تقليدها وتقديها من قبل الفنادق المنافسة ) بمتوسط حسابي (3.97) وانحراف معياري (0.999)

ونلاحظ بان سعي الادارة لتحقيق التميز بالاعتاد على المعلومات لتقديم خدمات الفندقية من قبل الفنادق المنافسة كانت بشكل اقل من اعتادها على باقي الفقرات وبناءا على الخفاض الوسط الحسابي من الاوساط الاخرى .

وكذلك تم استخراج الاوساط الحسابية والانحرافات المعيارية لفقرات توظيف التكنولوجيا الفندقية في الميزة التنافسية في فنادق مدينة دهوك و كمافي الجدول(16) : جدول 16

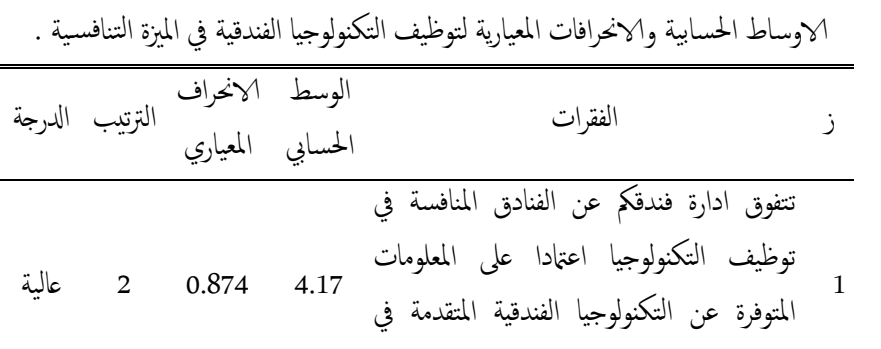
قاعدة بياناتها . تثنوق ادارة فندقكم عن الفنادق المنافسة في

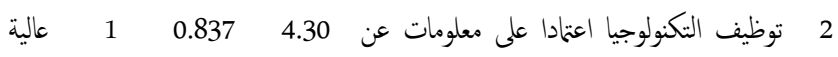

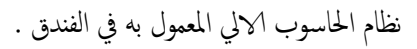

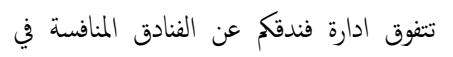
3 مقارنة مع الفنادق العالمية . تتفوق ادارة فندقكم عن الفنادق المنافسة في

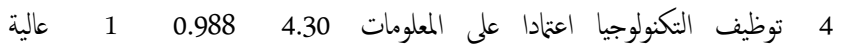
المناحة عن قواعد المعرفة للفنادق المتاحة .

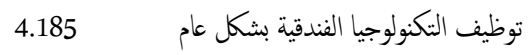

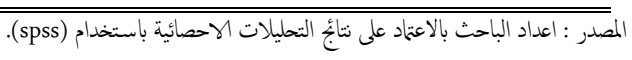




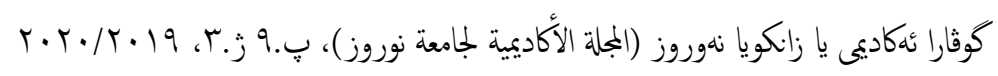

(19) عدم وجود عقة معنوية لمميع متغيرات الدراسة لعدم قدرتها على اجتياز اختبار ( t ) باستثناء متغير الاستخبارات الذي ظهرت معلمته بقيمة ( 2.865 ) وعند مستوى معنوية اقل من ( 5\% ) ، الا ان الجدول بين عدم ملائمة الأموذج احصائيا بدلالة قيمة ( F ) المسوبة والتي بلغت معنويتها الاحصائية اكبر من ( 5\% ) ، مما يشير الى عدم ملائمة الأثموذج لتمثيل العلاقة بين المتغيرات التفسيرية و المتغير التابع ، ما يفسر وجود تدخل الادارة في الحصول على المعلومات حول الميزة التنافسية بشكل غير مباشر ولا يعتمدون على المعلومات التي تعكسها نظام المعلومات التسويقية .كما ان القوة التفسيرية (Adj.R²)

جدول 19

\begin{tabular}{|c|c|c|c|c|}
\hline \multicolumn{3}{|c|}{ الميزة التنافسية } & \multirow[t]{2}{*}{ المتغير المعتمد } & \\
\hline t.sig. & t.stat. & Coef.est. & & المتغيرات المسـ \\
\hline 0.926 & -0.094 & -0.014 & & السجلات \\
\hline 0.008 & 2.865 & 0.369 & & الاستخبارات \\
\hline 0.727 & 0.353 & 0.033 & & البحوث \\
\hline \multirow[t]{5}{*}{0.759} & -0.311 & -0.027 & & القرار \\
\hline & 0.254 & & & $\mathrm{R}^{2}$ \\
\hline & 0.134 & & & Adj. $R^{2}$ \\
\hline & 2.126 & & & $\mathrm{~F}$ \\
\hline & 0.107 & & & F-sig. \\
\hline
\end{tabular}

المصدر : اعداد الباحث بالاعتاد على نتائج التحليلات الاحصائية باستخدام spss.

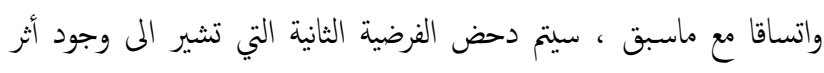
لعنصر نظام المعلومات التسويقية على الميزة التنافسية ، لعدم اختبار معنويتها .

4. 1.استنتاجات والمقترحات

1.4

بالرغ من تطور العلم والتكنولوجيا المعلومانية بشكل كير، الا ان معظم الفنادق في مدينة دهوك لم يستفاد من هذا التطور ولم يستخدموا التكنولوجيا المعلوماتية المتطورة بشكل جيد و فعال في الميزة التنافسية .
ولاختبار الفرضية التي تشير الى وجود اثر لعنصر نظام المعلومات التسويقية على الميزة التنافسية. سيتم اختبارها وفق مرحلتين، ففي المرحلة الاولى سيتم جمع و قياس متغيرات نظام المعلومات التسويقة على الميزة التنافسية بشكل اجلالي، وفي المرحلة الثانية، سيتم قياس متغيرات نظام المعلومات التسويقية بشكل منفرد على الميزة التنافسية : أ. تقدير أثموذج الأثر على الميزة الننافسية بشكل اجلالي: يبين الجدول (18) نتأُج معادلة الانحدار الخطي البسيط لقياس الأثر على الميزة التنافسية بوصفه متغيرا معتمدا مع بموعة من المتغيرات التفسيرية التي قد تؤخذ بنظر الاعتبار من قبل اصحاب الفنادق عند تحليل الحصة السوقية للفنادق او التبؤ بالميزة التنافسية لها والتي تتمثل بنظام المعلومات التسويقية خلال مدة البحث.

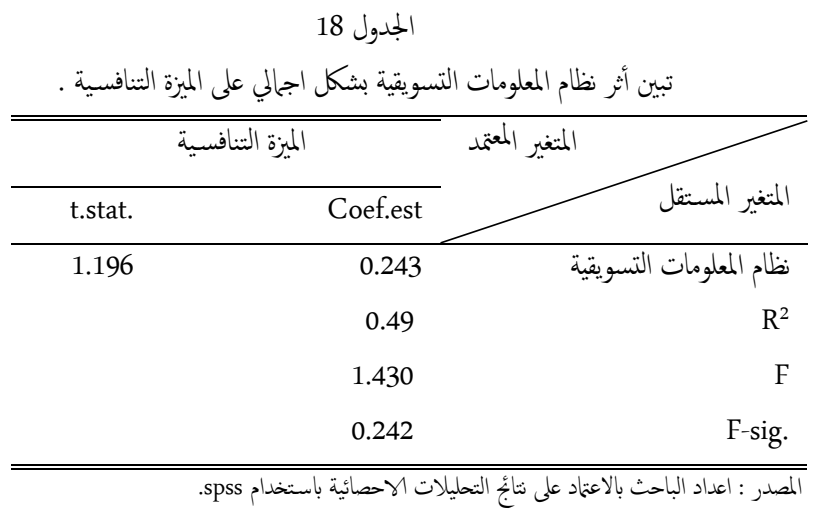
يتضح من الجدول ( 18) انه لا توجد علاقة معنوية ذات دلالة احصائية بين نظام المعلومات التسويقية و الميزة التنافسية وذلك من خلال ( t ) المحتسبة F ) للفنادق المبحوثة ، وكذلك عدم معنوية الأثموذج ككل من خلال احتساب ) المحتسبة ، والتي ظهرت في المعادلة بانها غير معنوية عند المستويات ( 1\% ) و ( \%5 ) لذا فان هذا يشير الى ان الميزة التنافسية للفنادق المبحوثة تعمد على معلومات تختلف المى حد كير عن المعلومات التي تعكسها نظام المعلومات التسويقية التي قد يعتمد عليها اصحاب الفنادق في السوق على الرغ من اهيتها كصدر لمعلومات ب. تقدير أثموذج الأثر على الميزة التنافسية بشكل منفرد : ييين الجدول ( 19) الأثر في الميزة الننافسية بعد ان تم ادخال متغيرات نظام المعلومات التسويقية بشكل منفرد الى الأثموج باستخدام معادلة الانحدار الخطي المتعدد ، ويؤشر الجدول 


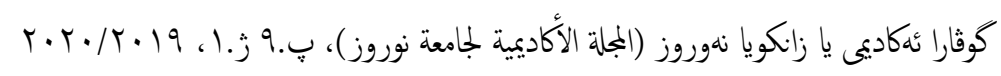

1. احمد عبداللطيف اليوسف : (2008) ، " استخدام الانتزيت في تلبية الطلب على الطئل

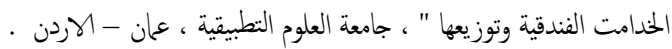

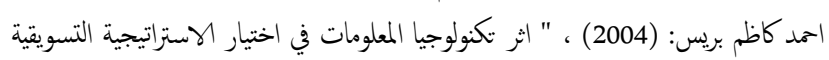

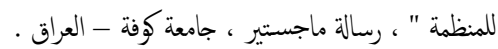

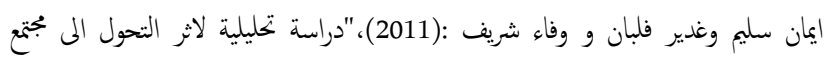

المعرفة في دع الميزة التنافسية لمؤسسات التعليم العالي بالمملكة العربية السعودية".

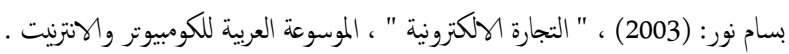

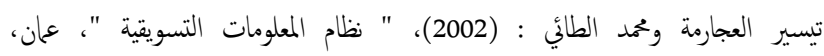

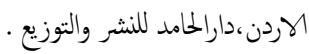

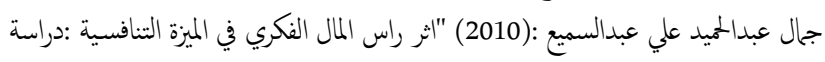
تطبيقة على بنوك القطاع العام التجاري " بجلة الدراسات والبحوث التجارية ، كلية التجارة ،

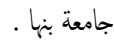
حسن علي وطلال عبود : (1999)، " الدراسات التسويقية ونظم المعلومات التسويقية "، دار الرضا للنشر ،لبنان .

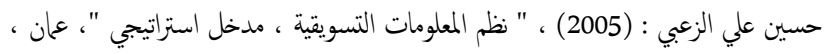
. الاردن

زيد عبوي : (2008) ، " نظم المعلومات التسويقية "، دار الراية، عان - مالاردن .

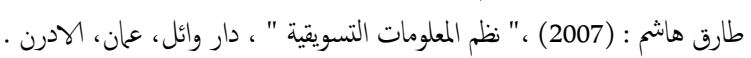

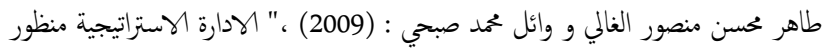

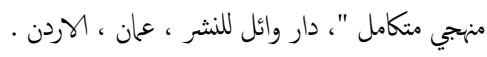

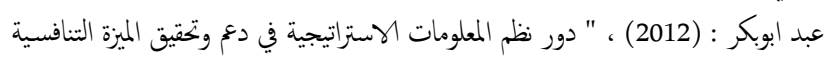

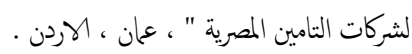

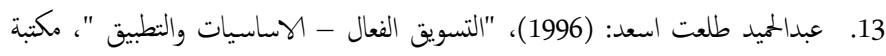
عين شمس ، مصر . 1.

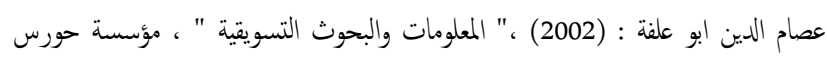

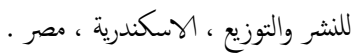
علي السلمي : (2001) ، " ادارة الموارد البشرية الاستراتيجية " ، دار غريب للنشر الطنر والطباعة ، القاهرة . 16. فيليب كتنلر : (2002) ، " التسويق ، اساليب التسويق الرئيسية "، ترجمة مازن نقاع،

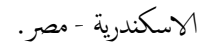

17. وئاد القاضي :(2021) ،"التخطيط الاستراتيجي لتحتيق الميزة التنافسية والخحافظة عليها "،

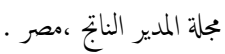

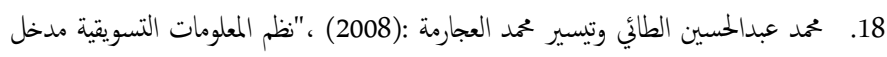

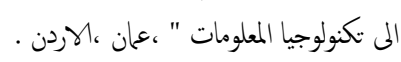

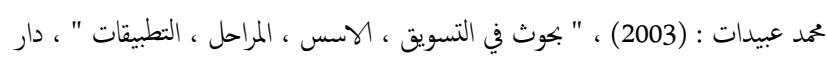
وائل ، الاردن .

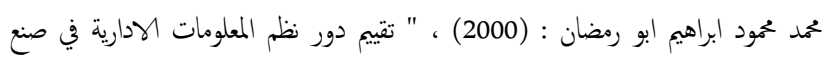

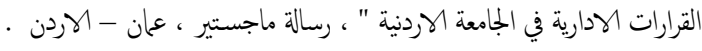

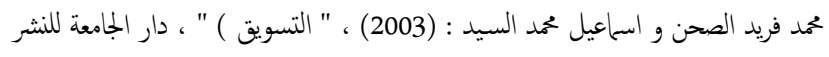

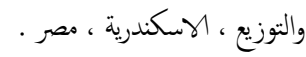

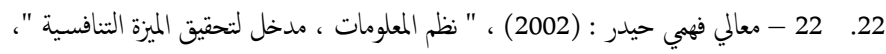
الدار الجامعية ، مصر . مالب ميكر :
من خلال هذه الدراسة تبين بان اصحاب الفنادق في مدينة دهوك لم مهتموا بالجانب العلمي اي المستوى التعليمي في ادارة الفندق ، بالرغز من وجود العديد من خريي الكليات والمعاهد السياحية في المدينة . من خلال هذا البحث تبين بانه لا توجد علاقة معنوية بين نظم المعلومات التسويقية و الميزة التنافسية بشكل عام، وهذا يدل على ان الميزة التنافسية للفنادق تعتمد على معلومات مختلفة الى حد كير عن المعلومات التي تعكسها نظام المعلومات التسويقية . من الدراسة تبين بانه يوجد علاقة معنوية ضعيفة بين الاستخبارات والميزة التنافسية بشكل منفرد، حسب اختبار (t) والذي ظهرت معلمته بقيمة (2.865) وعند المستوى المعنوية اقل من (5\%) ، بينما بدلالة ( F ) المحسوبة ، بلغت معنويتها اكبر من ( 5\% )، مما يشير الى عدم ملائمة النموذج، وهذا ما يفسر بوجود تدخل الادارة في الحصول على المعلومات حول الميزة التنافسية بشكل غير مباشر ولا يعتمد على نظم المعلومات التسويقية .

- 2.4 - المقترحات

من الضروري ان يقوم الفنادق في مدينة دهوك باستخدام التكنولوجيا المعلومانية المتطورة في فنادقهم والاستفادة منها في الميزة التنافسية . على الفنادق في مدينة دهوك الاستفادة من الكفاءات اي اصحاب الشهادات السياحية لادارة فنادقهم و ذلك لثقديم خدمات افضل للزبائن · من الضروري اقامة دورات تدربية للعاملين في الفنادق في مدينة دهوك وذلك لكي يتعرفوا على التطور التكنولوجي العلمي الحاصل و كيفية الاستفادة واستخدام هذا التطور في فنادقهم · ان تقوم الفنادق في المدينة بالتزويج والدعاية المستمرة داخل وخارج المدينة للخدمات الجيدة المقدمة من قبل الفندق مقارنة ببقية الفنادق . اجراء المزيد من الدراسات والابحاث التي ترتبط بالنظم المعلومات التسويقية و الميزة التنافسية . 5. المصادر 1.5 المصادر العربية 


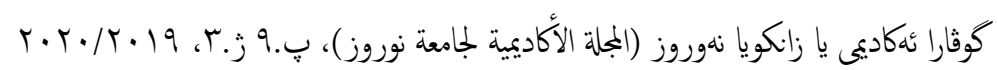

$$
\begin{aligned}
& \text { 23. معتز سلمان عبدالرزاق :(2008)،" اثر نظم المعلومات التسويقية في ضان جودة الحداء }
\end{aligned}
$$

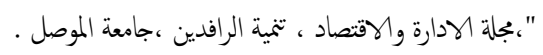

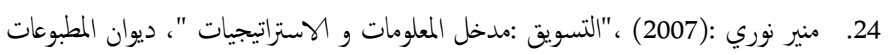

$$
\begin{aligned}
& \text { الجامعية ،الجزائر . } \\
& \text { 25. نبيل مرسي خليل : (1998) ، " الميزة التنافسية في جمال الوعال " ، مركز الهكندرية } \\
& \text { لمكتاب ، مصر . } \\
& \text { 26. نوري منير : (2007)، " ادارة العلا قة مع الزبائن كاداة لتحقيق الميزة التنافسية لمنظات }
\end{aligned}
$$

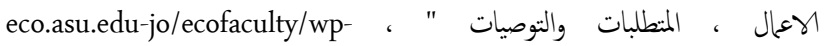

$$
\begin{aligned}
& \text {.content/.../70.doc. } \\
& \text { 27. وليد عبدالرمن خالد الفرا : (1430 هـ ) ) " تحليل بيانات الاستبيان باستخدام البرنامج } \\
& \text { الامصائي spss } \\
& 2.5
\end{aligned}
$$

1. Mark Colgate,2000, Marketing and Market information system sophistication in Retail Banking.

2. Philip Kotler, 1988, Marketing Management, Analysis Planning and Control, Prentice-Hall.

3. Philip Kotler, Kevin Keller, 2006, Marketing Management, Twelfth Edition, Northwestern university, Dartmouth collage.

4. Porter, Michael, 1993, E., Competitive advantage, N., Y., the Free press.

5. Weierbach, K. L. (2015). HR consultants: Enabling small business learers to establish sustainable competitive advantage (Datoral dissertationg Capella University)

6. William M. Pride O.C. Ferrell, 1989, Marketing Consepts and strategies, sixth edition, Texas A\&M University. 